\title{
TREE WOUND REACTIONS OF DIFFERENTLY TREATED BOREHOLES
}

\author{
by Dirk Dujesiefken, Andreas Rhaesa, Dieter Eckstein, and Horst Stobbe
}

\begin{abstract}
Holes from increment borings create wounds that lead to discoloration and may result in a colonization of the wood by fungi. There are various opinions about the damage caused by such borings and about the efficacy of wound dressings. For this reason, 78 differently treated boreholes in large-leaved lime (Tilia platyphyllos Scop.) and small-leaved lime (Tilia cordata Mill.), as well as in horsechestnut (Aesculus hippocastanum L.) and silver birch (Betula pendula Roth), were examined macroscopically and microscopically with regard to the wound reactions nearly 10 years after boring. Obvious differences in wound reactions were observed among the tree species. Both species of lime compartmentalized the wounds very effectively. Horsechestnut, on the other hand, revealed more extensive discoloration. Silver birch had the weakest compartmentalization, with discoloration up to $2 \mathrm{~m}(6.6 \mathrm{ft})$ in length. Cambial dieback around all borings, except for those plugged with creosote-impregnated wood dowels, was approximately the same for all species. Fungi occurred only within the discoloration. Cell wall disintegration was rarely observed. Treatment with LacBalsam ${ }^{\circledR}$ or polyurethane had little or no influence on the wound reactions. Boreholes sealed with impregnated wood dowels had far-reaching discoloration and cambial dieback as a result of the toxic effect of creosote.

Key Words. Increment borings; wound reaction; discoloration; decay; compartmentalization; cambial dieback; wound treatment.
\end{abstract}

Boreholes are made in trees for different reasons, for example, to examine street trees to ensure public safety (Mattheck and Breloer 1994) or in the forest to determine age and growth of trees (Eckstein 1985). The effects of such holes in forest trees have been studied as early as the 1930s and 1940s (Meyer and Heyward 1936; Lorenz 1944; Hepting et al. 1949). Discolored wood has been shown to extend from the wounds and is sometimes associated with decay caused by fungi. In the 1960s (Schöpfer 1961; Beisel et al. 1967), it was shown for spruce and beech that dressing wounds did not lead to any improvement in the wound reaction. However, such observations should be made long-term, and most of the aforementioned results stem from trials that lasted only 1 to 3 years. Therefore, statements with regard to discoloration, cambial dieback, and the effect of wound dressings are controversial.

The objective of this study was to examine the wound reactions after nearly 10 years of differently treated holes bored into deciduous trees.

\section{MATERIALS AND METHODS}

Three large-leaved limes (Tilia platyphyllos Scop.), 3 small-leaved limes (Tilia cordata Mill.), 4 horsechestnuts (Aesculus hippocastanum L.) and 6 silver birches (Betula pendula Roth) were used. With an increment borer, holes were bored into the lower trunks in April 1986 or March 1987. One borehole in each tree was left untreated (control wound) and the others were treated with 3 different wound dressings: LacBalsam ${ }^{\circledR}$ (Scheidler, Minden, Germany); a 1component filler on a polyurethane base (Sikaflex ${ }^{\circledR}$ 221 of Sika Chemie, Stuttgart, Germany); and, except for the silver birches, a wood dowel impregnated with creosote. The 3 large-leaved limes and 2 horsechestnuts had 2 boreholes of each treatment. A total of 78 wounds were investigated, and the trees were felled nearly 10 years after treatment.

Sections taken from the trunks of the lime and horsechestnut trees were appraised in accordance with Figure $1 \mathrm{a}-\mathrm{d}$ (all figures are at the end of this article) to determine the axial discolorations and to measure the cambial dieback. The longest and shortest discolorations of each dressing variant were selected for light-microscopic examinations. In the case of silver birch, the trunks were cut into sections 20-cm (8-in.) long, starting from the boreholes, to determine the axial extent of the discoloration. The sections containing the boreholes were cut open in the axial direction and cambial dieback was measured. For each of the 3 treatment options, small sample blocks were taken from the interior of the discoloration and from the edge of the discoloration 
(marginal zone) for light-microscopy. Cross-sections, radial sections, and tangential sections, 20 to $25 \mu$ thick, were stained with safranine ( $1 \%$ aqueous) and astrablue ( $0.5 \%$ aqueous) to enhance the contrast between the xylem tissue and fungal hyphae; Lugol solution was applied for the observation of starch in the parenchyma.

Because of the small sample size of the different variants of the study design, no rigorous statistical significance tests were applied. For each treatment, the median and range of the measurements and observations are given and tendencies described.

\section{RESULTS}

\section{Cambial Dieback and Discoloration}

After the increment boring, the cambium around the borehole died, especially in the axial direction. The length of the cambial dieback can be reconstructed years later because of the different wood formation in this area.

For all tree species, the extent of the cambial dieback around the boreholes (for an example, see Figure 2) was the same (Figure 3); however, for the impregnated-wood-dowel variant applied to largeleaved lime and horsechestnut, cambial dieback was up to $125 \mathrm{~mm}$ ( $5 \mathrm{in}$.) in length.

The tree species examined had similar wound reactions. Xylem discoloration extended from the borehole in an axial direction (for an example, see Figure 4), which frequently became longer towards the middle of the trunk and was only a few millimeters wide in a tangential direction. The discoloration was separated from the healthy, nondiscolored tissue by a dark line-the marginal zone. The length of discoloration varied between tree species and variants of treatment (Table 1).

In the limes, xylem discoloration was clearly zoned and-directly around the borehole-was ring-shaped and light brown. In the axial direction, an area with a brown discoloration followed. Its length was the shortest among the tree species studjed. In the horsechestnuts, the discolorations were longer than those of the limes. However, silver birches had discolorations with lengths of up to 200 $\mathrm{cm}$ (80 in.).

\section{Description of the Discoloration}

For all tree species and dressing variants, there was a zone within the discoloration that extended outwards from the borehole and in which few vessels were filled with accessory substances. In single cases, contents were found in the axial parenchyma, at the borders of the annual rings, and in the wood rays. The marginal zones were of different widths and differed with regard to the quantity of contents (Figure 5 and Figure 6). There were many closed vessels, and the wood rays and fibers were filled with accessory substances. In the sound tissue directly surrounding the discoloration, only the vessels had contents that decreased with the distance from the marginal zone. No differences were notable between the wound reactions at depths of 4 and $8 \mathrm{~cm}(1.6$ and 3.2 in.) at the boreholes. Fungi occurred only within the discoloration. The number of hyphae decreased from the borehole to the marginal zone. Cell-wall disintegration was rarely observed. No mycelium appeared around the borehole filled with LacBalsam up to a depth of $4 \mathrm{~cm}$ (1.6 in.) or with polyurethane to the full depth. Varying amounts of starch were found close to the marginal zone in tissue that was not discolored.

Lime trees had the highest density of accessory substances in the discoloration. The vessels, wood rays, fibers, and parenchyma cells were totally or partially filled by plugs. Few substances were found around the borehole, and only some vessels were filled with homogenous contents. In some wood rays and axial parenchyma cells, these substances were granular in structure. The deposits were more numerous in the area between nondiscolored and discolored: Most of the vessels and parenchyma cells, and many of the fibers within a width of 1 to $2 \mathrm{~mm}$ ( 0.03 to $0.06 \mathrm{in}$.) were filled and thus formed the marginal zone. 
The vessels, wood rays, and fibers of the horsechestnuts were also filled with deposits. The marginal zone was not as wide as that of the lime trees, and mainly the wood rays had contents. In the sound tissue, a large amount of starch was in the wood rays and axial parenchyma up to the marginal zone.

Silver birches had the least quantity of accessory substances in the discoloration. The vessels showed a membranous layer on the scalariform perforations, which were encrusted with fine granular material. Septa were observed in the fibers, and deposits were rarely found within the discolored zones. The marginal zone was very weak. Only a few vessels had contents, and then mainly at the cell wall. This zone, which was visible macroscopically, was formed by a row of fibers filled with homogenous contents (Figure 7 and Figure 8). Starch was found in the wood rays and axial parenchyma outside the discoloration.

\section{DISCUSSION}

Holes made with an increment borer wound the tree and result in discolorations in the woody tissue. Air embolisms interrupt the water flow through the vessels. Microorganisms can colonize the wood through the borehole; thus, the tree compartmentalizes this area and separates it from sound tissue.

The intensity of compartmentalization in lime, horsechestnut, and silver birch varied greatly. All 3 species contained a large amount of accessory substances in the marginal zone. In the nondiscolored zones, the contents are probably phenols that have not condensed completely or that are at primary stages of development (Dujesiefken et al, 1989). This is a wound reaction in front of the marginal zone that represents the real protection and, together with the marginal zone, prevents microorganisms from attacking healthy tissue (Aufsess 1975). There is evidence that colonization of the wood by decay fungi is unlikely because hyphae detected around the boreholes belong to fungi (known as pioneers) that are unable to cause a breakdown of the woody cell wall (Schwarze and Engels 1997).

The limited area of discoloration and the high quantity of deposits in the marginal zone suggest that limes have the strongest wound reactions of the tree species examined. The horsechestnuts and silver birches also form a marginal zone after being wounded, but the amount of cell content varies. The horsechestnuts appear to react more strongly than the silver birches, although their marginal zone is not as distinct as that of the limes. In contrast, the silver birches produce only a small quantity of cell deposits. Consequently, the axial discolorations can be up to $2 \mathrm{~m}(6.6 \mathrm{ft})$ in length. Septated fibers occur frequently in the discoloration of birch. The formation of a "primary wall-like layer" seems to increase the strength of the wound reaction because it temporarily reduces the degeneration of the parenchyma cells and thus enables further building of cell contents. An electron-microscopic examination of wounded birch wood showed that these septa have a filamentous structure that is neither cell-wall material nor accessory contents (Dujesiefken et al. 1989). Such differences between tree species also has been observed for other types of wounds (Schöpfer 1961; Bauch et al. 1980; Bonsen 1991).

Starch was observed in varying concentrations in all tree species. In the course of wound reactions, starch is converted to organic contents and thus contributes to the sealing of cell tissue and, above all, vessels (Buhl 1968; Blanchette and Biggs 1992).

The length of discoloration around boreholes in small-leaved lime and silver birch treated with LacBalsam was slightly shorter than that of the controls. For all species, no mycelium was detected as far as there was wound dressing in the borehole (mostly up to $4 \mathrm{~cm}$ [1.6 in.] depth). The different wound dressings appeared to have no influence on the length of cambial dieback around the boreholes, with the exception of the creosote-impregnated wood dowels in large-leaved lime and horsechestnut, which led to extensive dieback.

It was shown earlier that some wound dressings (e.g., LacBalsam) result in less discoloration and cambial dieback as well as more callus growth in several deciduous tree species (Mercer 1983; Shigo and Shortle 1984; Balder 1992; Dujesiefken 1992). In this study, the discolored wood contained only a small amount of mycelium. Other wound treatment trials also did not result in the wood being free of microorganisms (Dujesiefken and Liese 1991; Dujesiefken 1992). Because treated wounds can scarcely be differentiated from controls after several years, doubts exist about whether wound dressings should be applied at all (Shigo 1991). The polyurethane filler, which has to date not been used in arboriculture, achieved an effect 
similar to LacBalsam. The polyurethane, however, fills the whole length of the borehole and thus makes it more difficult for air and microorganisms to penetrate. It appears to be suitable as a borehole sealant.

By far the longest discolorations and cambial dieback were found in the boreholes that had been sealed with creosote-impregnated wood dowels. Creosote is well known to prevent fungi from growing in timber. Ten years ago, creosote was commonly applied to tree wounds (ZTV-Baum 1981; ZTVBaumpflege 1987); however, the toxic components of this wood preservative caused the parenchyma cells and cambium to die (Balder 1992; Dujesiefken and Liese 1992), subsequently enlarging the original wound. Creosote neither protects nor promotes wound closure.

Reactions around untreated boreholes were studied to clarify whether a wound treatment is of any benefit at all. Only small differences between treated boreholes and the controls were observed. Studies over 5 to 7 years (Shigo 1986) also showed little differences between treated and untreated boreholes. Similar observations were made in a 2-year study period by Dujesiefken and Liese (1992).

\section{CONCLUSIONS}

In arboriculture and in forest management, increment borings in living trees cannot be completely avoided. However, there is sufficient knowledge about how to limit the extent of damage to trees. Wounds to deciduous trees are less serious in spring and summer than in autumn or winter (Lenz and Oswald 1971; Schmitt and Liese 1992). None of the wound treatments we applied had any clear advantage in comparison with untreated wounds. Due to their phytotoxic effect, wood dowels impregnated with creosote should not be used to plug wounds. To date, little is known about the efficacy of wound dressings at different times of the year. Furthermore, wounds inflicted below living branches and at the base of the trunk, as a rule, resist decay much more effectively than, for example wounds 1 to $3 \mathrm{~m}$ ( 3 to $10 \mathrm{ft}$ ) above ground (Shigo 1991). Boreholes angled away from the stem radius cause a greater degree of discoloration than straight borings (Shortle et al. 1985).

In this study, the observations are based on healthy trees only. However, particularly extensive discolora- tions can be caused by boring into already-decayed areas inside the trunk or into false heartwood. This breaks through the marginal zone of the damage in the stem and renews the danger of microorganisms reaching the healthy wood, causing more discoloration and decay (Shigo and Felix 1980; Shigo 1986). Apparently this can be prevented to a great extent by filling the borehole completely (e.g., with a wound dressing). Further studies are necessary to elaborate a practicable concept for the treatment of wounds after borings.

\section{LITERATURE CITED}

Aufsess, H.v. 1975. Über die Bildung einer Schutzsperre an der Astbasis von Laub- und Nadelbäumen und ihre Wirksamkeit gegen das Eindringen von Pilzen in das Kernholz lebender Bäume [On the formation of a protection zone at the base of branches of deciduous trees and conifers and its efficacy against the penetration of fungi into the heartwood]. Forstwiss. Cbl. 94:140-152.

Balder, H. 1992. Pflanzenverträglichkeit von Wundbehandlungen in der Baumpflege IOn the compatibility of wound treatments as regards arboriculture]. Gesunde Pflanzen 44:296-302.

Bauch, J., A.L. Shigo, and M. Stark. 1980. Wound effects in the xylem of Acer and Betula species. Holzforsch. 34:153-160.

Beisel, G., U. Nielsen., and J.J. Sauter. 1967. Schutzmaßnahmen gegen Schäden nach Zuwachsbohrungen [Measures to protect trees against damages after increment borings]. Allg. Forstz. 28:478-480.

Blanchette, R.A., and A.R. Biggs (Eds.). 1992. Defense mechanisms of woody plants against fungi. SpringerVerlag, Berlin and Heidelberg, Germany. 458 pp.

Bonsen, K.J.M. 1991. Gefäßverschluß-Mechanismen in Laubbäumen [Mechanisms of vessel closure of deciduous trees]. Vierteljahresschrift der Naturforschenden Gesellschaft in Zürich, 136/1:13-50.

Buhl, C. 1968. Wunden, pp 1-96. In Sorauer, P. (Ed.). Handbuch der Pflanzenkrankheiten [Textbook of Plant Diseases], Vol. I: Die Nichtparasitären Krankheiten [Nonparasitic Diseases]. Verlag P. Parey, Berlin and Hamburg, Germany.

Dujesiefken, D. 1992. Einfluß von Wundverschlußmitteln auf die Wundreaktionen von Bäumen [The influence of wound sealants on the wound reactions of trees]. Gesunde Pflanzen 44:306-311.

Dujesiefken, D., and W. Liese. 1991. Holzbiologische Untersuchungen zu Methoden der Baumpflege [Wood biological studies with regard to methods of arboriculture]. Naturschutz und Landschaftspflege in Hamburg Nr. 35:85-109. 
Dujesiefken, D., and W. Liese. 1992. Holzschutzmittel zur Wundbehandlung bei Bäumen? [Wood preservatives for the wound treatment of trees?]. Gesunde Pflanzen 44:303-306.

Dujesiefken, D., S. Ebenritter, and W. Liese. 1989. Wundreaktionen im Holzgewebe bei Birke, Buche und Linde [Wound reactions in the xylem of birch, beech, and lime]. Holz Roh-Werkst. 47:495-500.

Eckstein, D. 1985. On the application of dendrochronology for the evaluation of forest damage. Proc. IUFRO Conf. on Inventorying and Monitoring Endangered Forests, Zürich, 87-290.

Hepting, G.H., E.R. Roth, and B. Sleeth. 1949. Discoloration and decay from increment borings. J. For. 47:366-370.

Lenz, O., and K. Oswald, 1971. Über Schäden durch Bohrspanentnehme bei Fichte, Tanne und Buche [On damages by increment boring in spruce, fir, and beech]. Mitt. Schweiz. Anst. Forstl. Versuchsw. 47:1-27.

Lorenz, R.C. 1944. Discolorations and decay resulting from increment borings in hardwoods. Forestry 42:37-43.

Mattheck, C., and Breloer, H. 1994: The Body Language of Trees. A Handbook for Failure Analysis. Research for Amenity Trees No. 4, Department of the Environment, HMSO, London, UK. 240 pp.

Mercer, P.C., 1983. Callus growth and the effect of wound dressings. Ann. Appl. Biol. 103:27-540.

Meyer, W.H., and S.B. Hayward. 1936. Effect of increment boring on Douglas fir. J. For. 34:867-869.

Schmitt, U., and W. Liese. 1992. Seasonal influence on early wound reactions in Betula and Tilia. Wood Sci. Technol. 26:405-412.

Schöpfer, W. 1961. Die Bohrspanentnahme von Waldbäumen [Coring in forest trees]. Allg. Forstz. 19:297300.

Schwarze, F, and J. Engels. 1997. Bohrtechniken bei der Ermittlung der Bruch- und Standsicherheit pilzinfizierter Bäume [Boring techniques to determine the security of trees infected by fungi]. Neue Landschaft 4:261-272.

Shigo, A.L. 1986. A New Tree Biology. Shigo and Trees, Associates, Durham, NH. 618 pp.

Shigo, A.L. 1991. Modern Arboriculture. Shigo and Trees, Associates, Durham, NH. 424 pp.

Shigo, A.L., and R. Felix. 1980. Cabling and bracing. J. Arboric. 6:5-9.

Shigo, A.L., and W.C. Shortle. 1984. Wound dressings: Results of studies over thirteen years. Arboric. J. 8:193-210.

Shortle, W.C., K.T. Smith, K.R. Dudzik, and S. Pasher. 1985. Response of maple sapwood to injury and infection. Eur. J. For. Path. 25:241-252.
ZTV-Baum. 1981. Zusätzliche technische Vorschriften und Richtlinien für Baumpflege- und Baumsanierungsarbeiten (Entwurf) [Technical Regulation Guidelines for Arboriculture (draft)]. Oberfinanzdirektion Stuttgart. $34 \mathrm{pp}$.

ZTV-Baumpflege, 1987. Zusätzliche Technische Vorschriften und Richtlinien für Baumpflege und Baumsanierung [Technical Regulation Guidelines for Arboriculture]. 1. Auflage, Schriftenreihe der Forschungsges. Landschaftsentwicklung-Landschaftsbau (FLL), Bonn, Germany. 34 pp.

Acknowledgements. We dedicate this article to Dr. Günther Seehann, Reinbek/Germany, an impassioned lover of trees, at the occasion of his retirement.

Institute for Arboriculture

Brookkehre 60

21029 Hamburg

Germany

Institute for Wood Biology

University of Hamburg

Leuschnerstr 91

21031 Hamburg

Germany

Résumé. Les trous créés par les sondes causent des blessures qui produisent des décolorations du bois et peuvent provoquer une colonisation de ce dernier par des champignons de carie. Il y a encore plusieurs opinions à propos des dommages causés par ce type de sondes et sur l'efficience des enduits sur les blessures causées. Dans cette optique, un total de 78 trous faits dans du tilleul à grandes feuilles (Tilia platyphyllos Scop.), du tilleul à petites feuilles (Tilia cordata Mill.), du marronnier d'inde (Aesculus hippocastanum L.) et du bouleau pleureur (Betula pendula Roth) et qui ont été traités de façons variables ont été examinés à l'échelle macroscopique et aussi microscopique en regard des réactions des blessures environ 10 ans après le forage des trous. Il y avait des différences évidentes dans les réactions des blessures entre les espèces d'arbres; les deux espèces de tilleuls compartimentaient les blessures de façon très efficiente. D'un autre côté, le marronnier présentaient des zones de décoloration plus importantes. Le bouleau pleureur avait le plus faible degré de compartimentation, les zones de décoloration s'étendant jusqu'à deux mètres en longueur. La mortalité du cambium autour de tous les trous était la même pour 
toutes les espèces à l'exception des arbres dont les trous étaient bouchés avec une cheville de bois imprégnée de créosote. Les caries étaient seulement présentes à l'intérieur des zones de décoloration. La désintégration des parois cellulaire était rarement observée. Un traitement avec du LacBalsam ${ }^{\circledR}$ ou du polyuréthane n'avait que peu ou pas d'effet sur les réactions de la blessure. Les trous scellés avec des cheville de bois imprégnées de créosote avaient atteints des degrés élevés de décolorations et de mortalité du cambium en raison de la toxicité associée à ce produit.

Zusammenfassung. Um die Wundreaktion und die Effektivität von drei Wundbehandlungen zu bestimmen, wurde 10 Jahre nach dem Anbohren die Wundreaktion in Bohrlöchern bei groß- und kleinblättrigen Linden (Tilia spp.), Roßkastanien (Aesculus hippocastaneum) und Silberbirken (Betula pendula) mikro- und makroskopisch gemessen. Alle Verletzungen wurden in einer Jahreszeit vorgenommen, die günstig für die Kompartmentalisierung ist. Die Wunden wurden mit LacBalsam ${ }^{\circledR}$, Polyurethan und mit kreosot-getränkten Dübeln behandelt. Bei allen Bohrungen war das Rücksterben des Kambiums gleichstark, mit Ausnahme der Löcher, die einen kreosotgetränkten Dübel enthielten: dort gab es viel stärkere Absterbeerscheinungen. LacBalsam und Polyurethan hatten nur wenig Einfluß auf die Wundreaktion, während die Verfärbungen viel aufgedehnter waren als bei den kreosot-getränkten Dübeln. Die Linden kompartmentalisierten die Wunden sehr effektiv, während die Roßkastanien wesentlich mehr verfärbungen aufwiesen. Die Silberbirken wurden als sehr schwache Kompartmentaliseirer eingestuft.
Resumen. Los huecos de las perforaciones crean heridas, las cuales dejan decoloraciones que pueden resultar en una colonización de la madera por hongos. A ún existen diferentes opiniones acerca del daño causado por tales perforaciones y de la eficacia de las pinturas de heridas. Por esta razón, un total de 78 huecos perforados, diferentemente tratados, en tilos grandes (Tilia platyphyllus Scop.) y tilos pequeños ( $T$. cordata Mill.) como también en castaño de Indias (Aesculus hippocastanum L.) y abedul plateado (Betula pendula Roth), fueron examinados macroscópica y microscópicamente con el objeto de ver las reacciones de las heridas aproximadamente 10 años después de las perforaciones. La diferencia en las reacciones fue obvia entre las tres especies; ambas especies de tilo compartimentaron muy efectivamente las heridas. El castaño de Indias, por otro lado, reveló decoloraciones más extensivas. El abedul plateado tuvo la compartimentación más débil, con decoloraciones de más de dos metros de longitud. La muerte del cambium alrededor de todos las perforaciones fue la misma para todas las especies excepto para aquellas taponadas con clavos de madera impregnados con creosota. Los hongos estuvieron solamente dentro de la decoloración. La desintegración de la pared celular raramente fue observada. Los tratamientos con LacBalsam o poliuretano tuvieron poca o nula influencia sobre las reacciones de las heridas. Los huecos de las perforaciones sellados con clavos de madera impregnados, alcanzaron decoloraciones y muerte del cambio como un resultado del efecto tóxico de la creosota. 
(a)

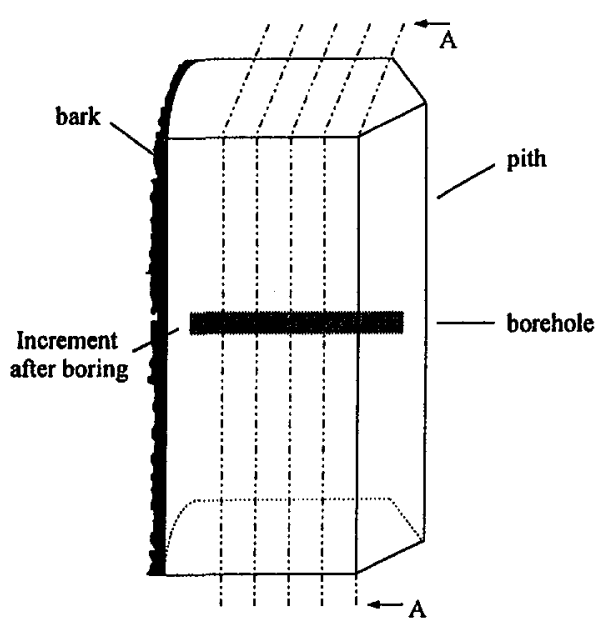

(c)
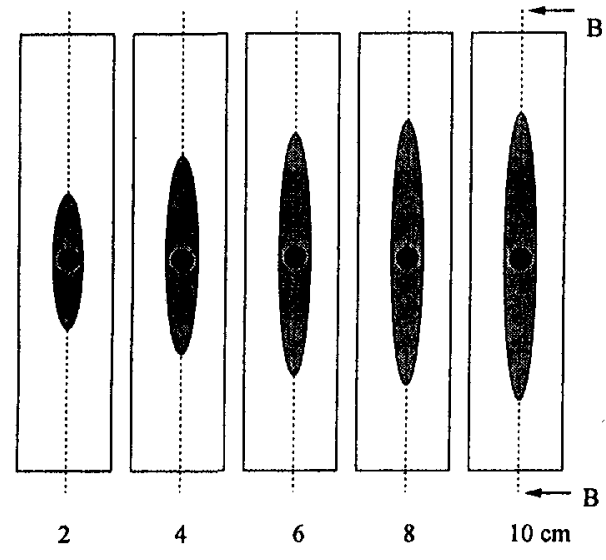

depth of borehole (b)

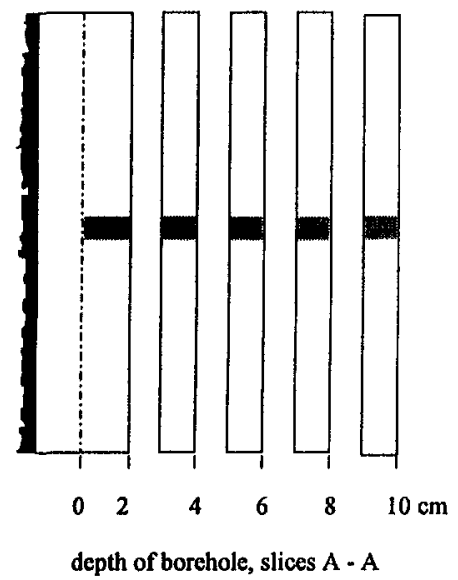

(d)

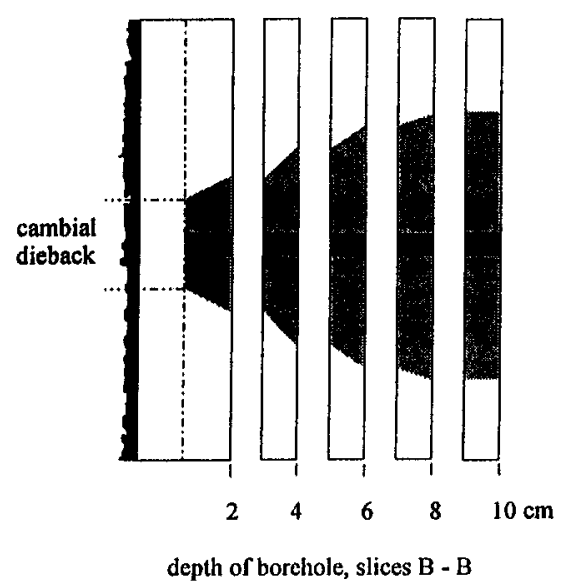

Figure 1. Preparation of sample. (a) trunk segment with a borehole inside before dividing into slices; (b) dividing the segment in tangential direction in slices of $2 \mathrm{~cm}$ thickness each; (c) discoloration caused by a borehole in different depths, tangential view; (d) discoloration and cambial dieback caused by a borehole in different depths, radial view. 


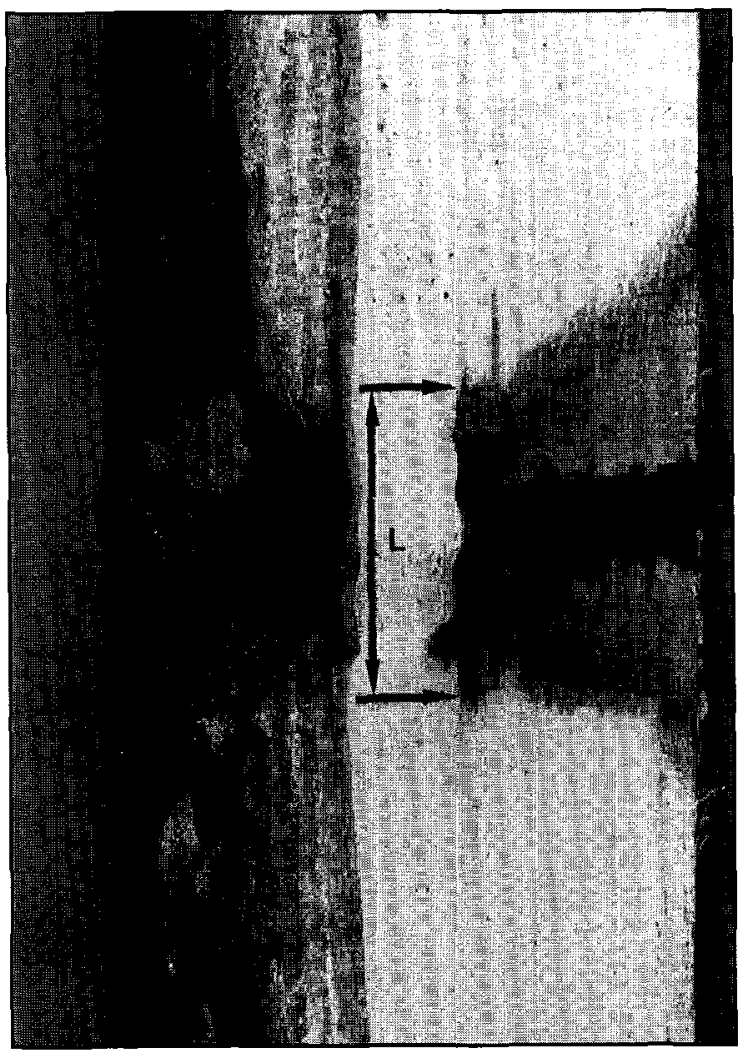

Figure 2. Length of initial cambial dieback (L) after wounding of a large-leaved lime; the borehole is filled with polyurethane.

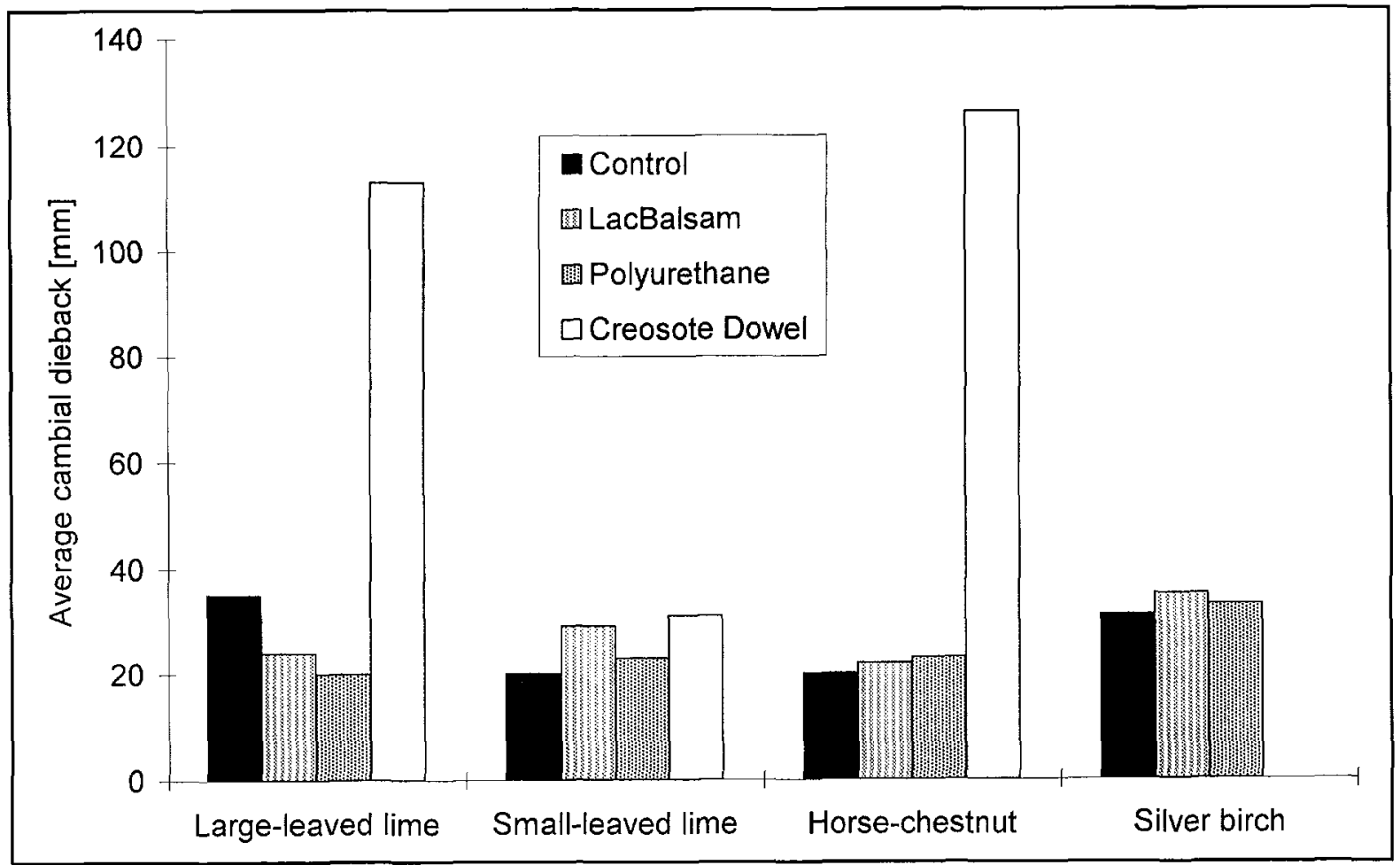

Figure 3. Average cambial dieback around boreholes with different treatments. 

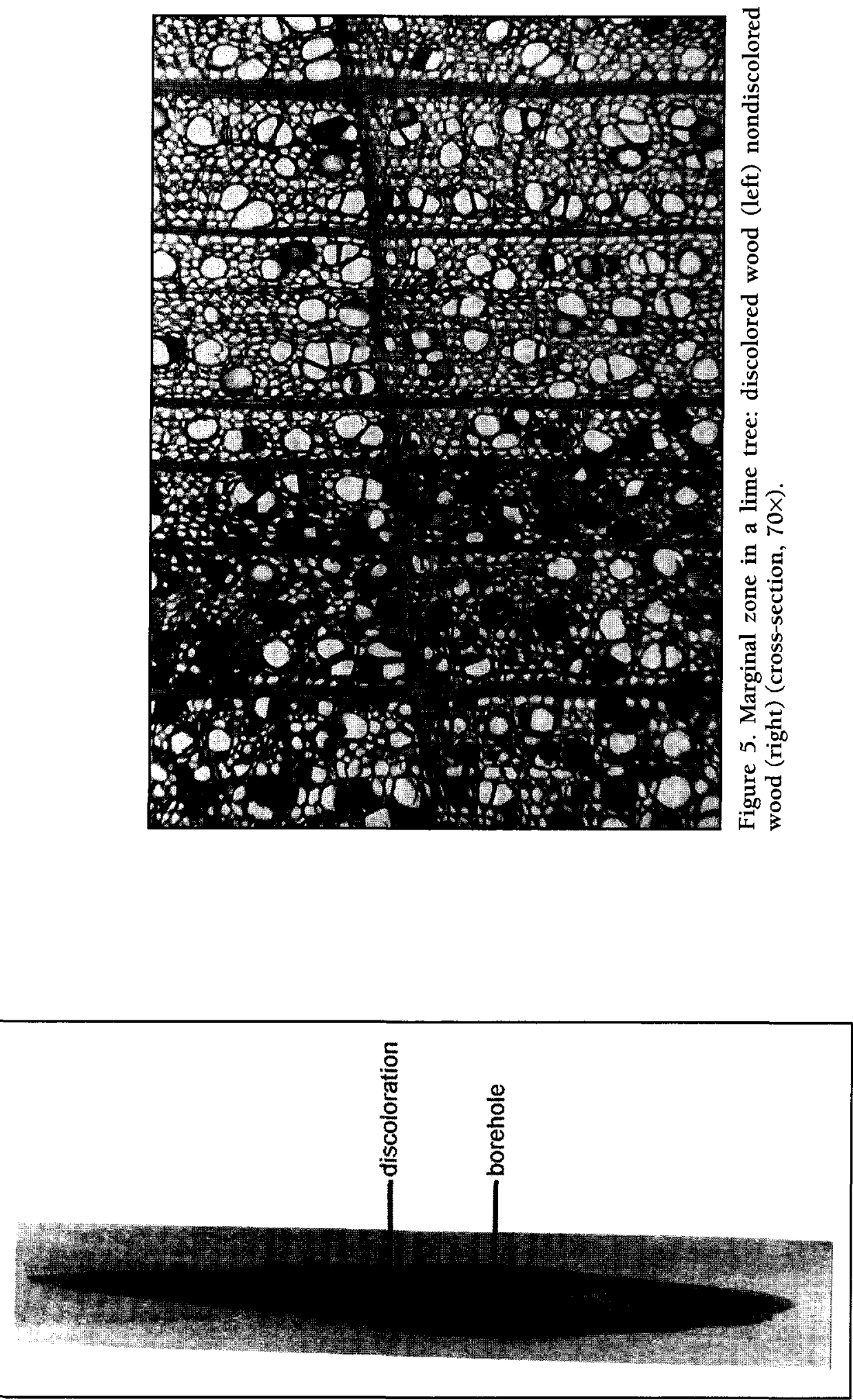

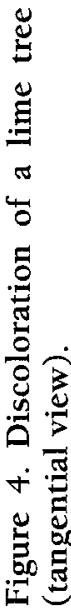



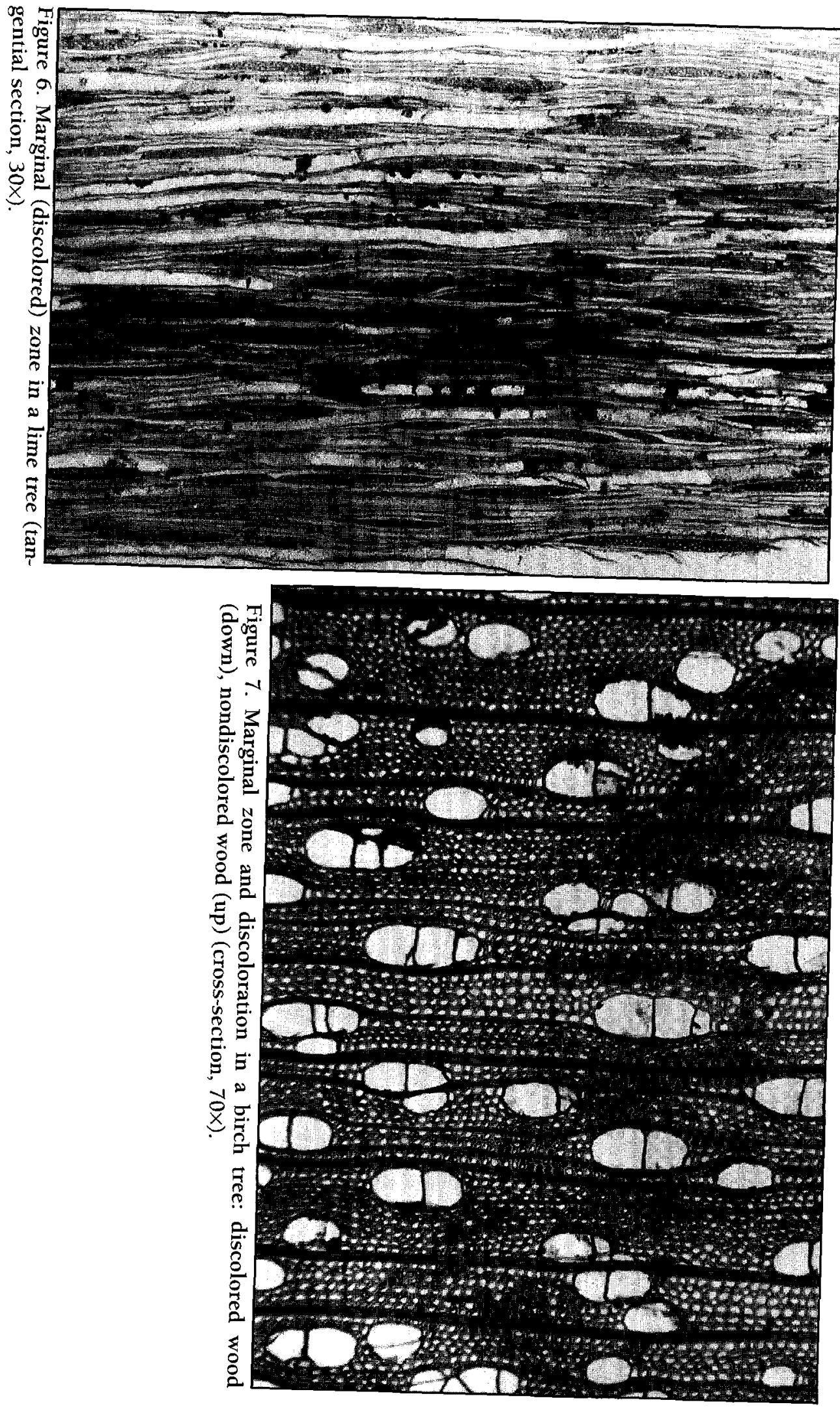


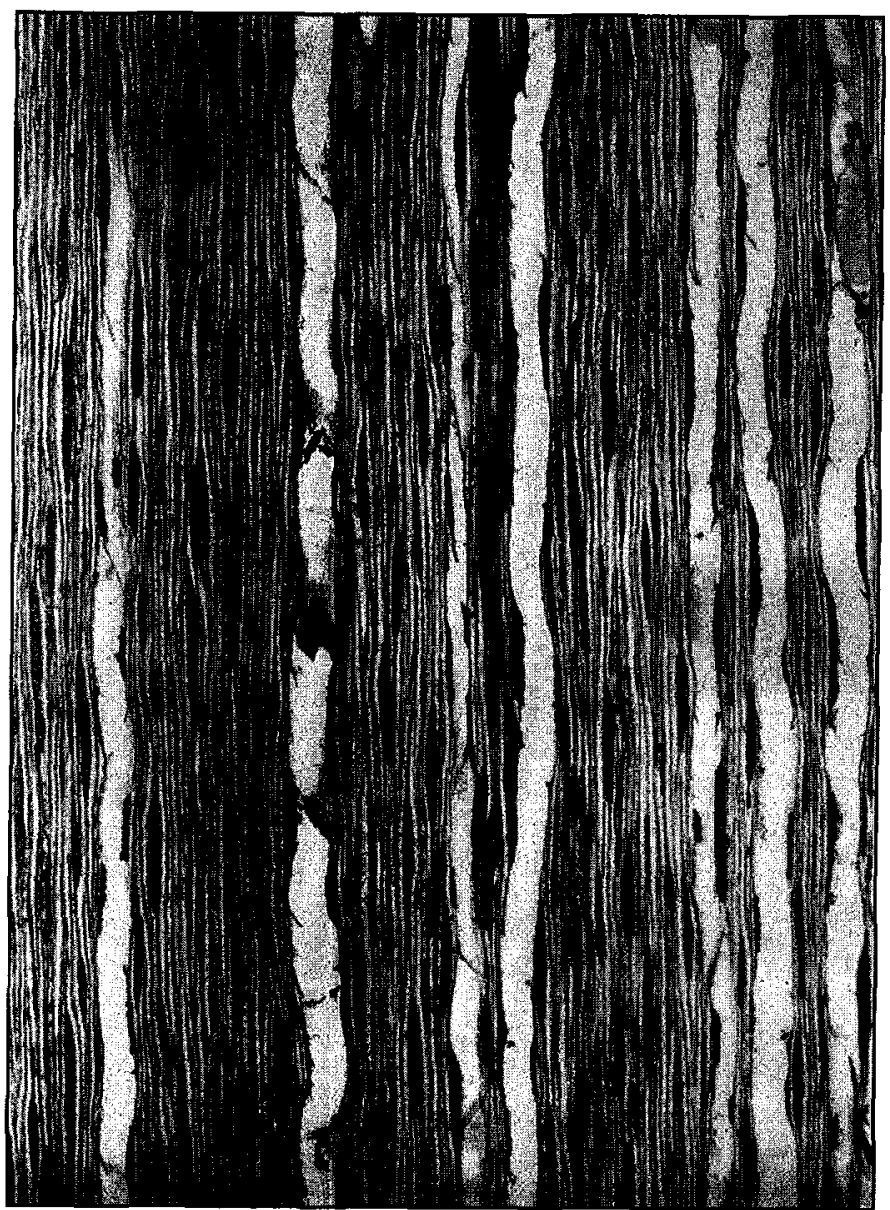

Figure 8. Marginal zone in a birch tree (slightly discolored) (tangential section, $30 \times$ ). 